\title{
INDEKS PEMAKAIAN AIRTANAH DI KOTA YOGYAKARTA
}

\section{Ahmad Cahyadi', Indra A. Riyanto², Hendy Fatchurohman ${ }^{3}$, Sigit H.M.B. Santosa ${ }^{4}$, Raras Endarto 5}

\author{
'Departemen Geografi Lingkungan, Fakultas Geografi, Universitas Gadjah Mada \\ Jalan Kaliurang km. 4,5 Bulaksumur, Depok, Sleman, DI Yogyakarta \\ ${ }^{2}$ Lentera Geosains \\ Jalan Tongkol V, RT 08, No. 18, Minomartani, Ngaglik, Sleman, DI Yogyakarta \\ ${ }^{3}$ Departemen Teknologi Kebumian, Sekolah Vokasi, Universitas Gadjah Mada \\ Jalan Kaliurang km. 4,5 Bulaksumur, Depok, Sleman, DI Yogyakarta \\ ${ }^{4}$ Departemen Sains Informasi Geografi, Fakultas Geografi, Universitas Gadjah Mada \\ Jalan Kaliurang km. 4,5 Bulaksumur, Depok, Sleman, DI Yogyakarta \\ ${ }^{5}$ PT Citra Gama Sakti \\ Jalan Gejayan No. 76, Deresan, Depok, Sleman, DI Yogyakarta \\ Email corresponding: ahmad.cahyadi@ugm.ac.id
}

\begin{tabular}{|c|c|c|}
\hline Dikirimkan: & Diterima: & Diterbitkan: \\
$11-04-2020$ & $24-06-2020$ & $27-07-2020$ \\
\hline
\end{tabular}

\begin{abstract}
The rapid development of the city causes an increase in the amount of water that needed to support various activities. The Utilization of groundwater in large quantities causes negative impacts such as the decrease in groundwater level so that people are difficult to access groundwater. The aim of this study is to analyze the index of groundwater use which describe the condition of groundwater use in the city of Yogyakarta. The groundwater use index is calculated by dividing the total water demand and the availability of groundwater in the City of Yogyakarta. The result shows that in general groundwater use in the city of Yogyakarta is categorized in the safe enough classification (III). However, in the shallow groundwater use index there is one area with less safe classification (II) namely Kotagede District, and one area with unsafe classification (I) namely Umbulharjo District. The main factor which influence to the high index of shallow groundwater use is large population that causes high water domestic needs. This is reflected in the percentage of water domestic needs reaching $90.43 \%$.
\end{abstract}

Keywords: Groundwater, Index of Groundwater Use, Yogyakarta City

\begin{abstract}
Abstrak
Perkembangan kota yang pesat menyebabkan semakin banyak jumlah air yang dibutuhkan untuk menunjang berbagai kegiatan di dalamnya. Pemanfaatan airtanah dalam jumlah yang besar menyebabkan dampak negatif seperti penurunan muka airtanah, sehingga masyarakat sulit untuk mengakses airtanah tersebut. Penelitian ini bertujuan menganalisis indeks pemakaian airtanah yang diharapkan dapat menggambarkan kondisi penggunaan airtanah di Kota Yogyakarta. Indeks pemakaian airtanah dihitung dengan membagi total kebutuhan air dengan ketersediaan airtanah di Kota Yogyakarta. Hasil analisis menunjukkan bahwa secara umum pemakaian airtanah di Kota Yogyakarta masuk dalam klasifikasi cukup aman (III). Namun demikian pada indeks pemakaian airtanah dangkal terdapat satu wilayah dengan klasifikasi kurang aman yakni Kecamatan Kotagede, dan satu wilayah dengan klasifikasi tidak aman, yakni Kecamatan Umbulharjo. Faktor utama yang berpengaruh tingginya indeks pemakaian airtanah dangkal adalah jumlah penduduk yang sangat besar yang menyebabkan kebutuhan air domestik yang sangat tinggi. Hal tersebut tergambar dari nilai persentase kebutuhan domestik yang mencapai 90,43\%
\end{abstract}

Kata Kunci: Airtanah, Indeks Pemakaian Airtanah, Kota Yogyakarta 


\section{PENDAHULUAN}

Airtanah merupakan salah satu sumberdaya air tawar yang paling banyak dengan banyak keunggulan dibandingkan dengan sumberdaya air tawar yang lain (Todd and Mays, 2005; Purnama, 2010). Jumlah airtanah diperkirakan sekitar 30,1\% dari jumlah air tawar di Bumi. Jumlah tersebut merupakan jumlah air tawar terbesar yang dapat dimanfaatkan karena $69,5 \%$ air tawar di bumi dalam bentuk es di wilayah kutub sulit untuk dimanfaatkan oleh manusia (Margat and van der Gun, 2013).

Airtanah juga memiliki banyak kelebihan dibandingkan dengan sumber air tawar yang lain (Purnama dkk., 2019). Beberapa kelebihan airtanah di antaranya adalah bahwa airtanah memiliki kualitas yang relatif baik karena terlindung pada lapisan batuan (akuifer) (Todd and Mays, 2005). Air yang masuk ke dalam akuifer mengalami filtrasi atau penyaringan secara alamiah oleh butir tanah dan batuan, sehingga kualitas airtanah menjadi relatif lebih dibandingkan dengan air permukaan atau air hujan (Purnama, 2010). Selain itu, airtanah tersedia dalam jumlah banyak dalam akuifer yang berarti bahwa airtanah tidak memerlukan tampungan yang luas yang mengahbiskan ruang di permukaan tanah. Kelebihan lain dari airtanah adalah bahwa airtanah mengandung banyak mineral dalam jumlah yang cukup untuk kehidupan manusia (Santosa dan Adji, 2014). Mineral-mineral tersebut larut di dalam airtanah sebagai akibat dari interaksi antara air dan batuan dalam waktu yang cukup lama di dalam akuifer.

Pemanfaatan airtanah terus meningkat seiring dengan perkembangan perkotaan yang diikuti dengan jumlah penduduk yang semakin banyak dan semakin banyaknya kegiatan manusia yang membutuhkan sumberdaya air (Cahyadi et al., 2011). Kenaikan penggunaan airtanah telah menjadi isu sejak tahun 1950-an sejak kota-kota di dunia mengalami perkembangan yang pesat pasca perang dunia kedua (Howard, 2007). Permasalahan airtanah di perkotaan ini pertama kali diangkat sebagai isu dunia ketika dilangsungkan oleh UNESCO dengan tajuk "Hydrological Processes and Water Management in Urban Areas." International Association of Hydrogeologists (IAH) menanggapi masalah airtanah di perkotaan dengan membentuk komisi khusus airtanah perkotaan (urban groundwater) pada tahun 1993 di Oslo, Norwegia (Chilton, 1999). Kemudian di tahun 1997 untuk pertama kalinya konggres $\mathrm{IAH}$ ke-27 di Nottingham, Inggris diselenggarakan dengan tema "Groundwater in Urban Areas" (Chilton, 1997; Howard, 2007)

Salah satu kota di Indonesia yang memiliki perkembangan yang cukup pesat dari segi fisik kota adalah Kota Yogyakarta (Cahyadi dkk., 2011). Kota ini secara geologi merupakan salah satu bagian dari Cekungan Airtanah YogyakartaSleman yang memiliki potensi airtanah yang sangat tinggi. Perubahan penggunaan lahan dari lahan non terbangun menjadi lahan terbangun di Kota Yogyakarta cukup cepat terjadi. Hal ini tentunya akan berdampak pada imbuhan airtanah yang berkurang dan penggunaan air yang bertambah pula (Garcia-Fresca, 2007; Burn et al., 2007; Allen, 2007). Hal ini disebabkan oleh penambahan lahan terbangun identik dengan semakin banyak dan beragamnya aktivitas manusia yang membutuhkan air (Mohrlok et al, 2007; Miracapillo; 2007).

Berbagai masalah terkait airtanah di Kota Yogyakarta telah terjadi, di antaranya adalah terjadinya penurunan muka airtanah dan pencemaran airtanah (Tim Fakultas Geografi Universitas Gadjah Mada (UCM), 1996; Putra, 2003). Wilopo (1999) mengungkapkan bahwa hasil kajian multi temporal yang dilakukannya dengan data tinggi muka airtanah tahun 1983, 1995 dan 1998 menunjukkan bahwa airtanah di Cekungan Yogyakarta-Sleman (termasuk Kota Yogyakarta) mengalami penurunan mulai dari $0,324-0,514$ meter/tahun. Penelitian lain yang dilakukan oleh Sari (2015) menyebutkan bahwa dengan perkembangan yang konstan seperti saat ini maka pada tahun 2035 penurunan muka airtanah di Kota Yogyakarta dapat mencapai 22meter dari kondisi saat ini.

Perkembangan Kota Yogyakarta mengharuskan perencanaan yang baik, terutama terkait dengan penyediaan air bersih perkotaan. Hal ini agar sumberdaya airtanah tidak mengalami kerusakan di masa mendatang. Salah satu upaya yang dapat dilakukan di antaranya dengan melakukan evaluasi penggunaan sumberdaya airtanah menggunakan indeks pemakaian airtanah. Penelitian ini bertujuan untuk menghitung indeks pemakaian airtanah di Kota Yogyakarta. Dalam penelitian ini dianalisis potensi airtanah dinamis berdasarkan hasil kajian pustaka dan perhitungan kebutuhan air Kota Yogyakarta yang dianalisis berdasarkan data sekunder. Kajian ini diharapkan dapat memberikan masukan terkait dengan pengelolaan airtanah di Kota Yogyakarta pada masa mendatang. Indeks pemakaian airtanah adalah rasio dari kebutuhan air terhadap 
ketersediaan air. Dalam penelitian ini, diasumsikan pemanfaatan air yang terdapat di Kota Yogyakarta keseluruhannya dipenuhi dari airtanah.

\section{METODOLOGI PENELITIAN}

\section{Metode Perhitungan Potensi Airtanah Dinamis}

Perhitungan ketersediaan airtanah dalam penelitian ini didasarkan pada hasil kajian yang dilakukan oleh Tim Fakultas Teknik UCM tahun 2010, penelitian yang dilakukan oleh Hendrayana dan Vicente (2013) serta penelitian yang dilakukan oleh Tim Fakultas Geografi UGM (2014; 2015). Ketersediaan airtanah dinamis adalah ketersediaan air yang dinyatakan dengan debit airtanah yang mengalir pada suatu wilayah. Pengambilan airtanah yang sama atau kurang dari debit airtanah yang mengalir pada suatu wilayah dianggap tidak akan menyebabkan terjadinya kerusakan terhadap sumberdaya airtanah. Ketersediaan airtanah dinamis dalam penelitian ini dihitung untuk ketersediaan selama satu tahun.

Persamaan yang digunakan dalam perhitungan ketersediaan airtanah dinamis adalah persamaan 1. Ketersediaan airtanah dinamis $(Q=$ debit airtanah pada sistem akuifer yang ditinjau dalam satuan $\mathrm{m}^{3} /$ hari) bergantung pada nilai $T$ (transmisivitas atau koefisien keterusan $\mathrm{m}^{2} /$ hari), I (gradien hidraulik atau kemiringan muka airtanah) yang merupakan perbandingan beda tinggi muka airtanah per satuan jarak dan L (lebar penampang akuifer yang ditinjau dalam satuan meter). Nilai $T$ diperoleh dari persamaan 2, di mana $T$ dipengaruhi oleh nilai $\mathrm{K}$ (konduktivitas hidraulik dalam satuan meter/hari) dan b (ketebalan akuifer dalam satuan meter).

$Q=T . I . L$ (1) (Purnama, 2010)

$$
\text { di mana }
$$

$\mathrm{T}=\mathrm{K} \cdot \mathrm{b}$ (2) (Purnama, 2010)

\section{Metode Perhitungan Kebutuhan Air}

Perhitungan kebutuhan air didekati dengan rata-rata pemanfaatan air untuk setiap kegiatan. Data yang digunakan dalam perhitungan kebutuhan air diambil dari data kecamatan dalam angka tahun 2018 yang dipublikasikan oleh Badan Pusat Statistik (BPS). Perhitungan nilai kebutuhan air untuk domestik, industri, perkantoran, peternakan dan perikanan dihitung berdasarkan pada Standar Nasional Indonesia (SNI) 6728.1: 2015 tentang
Penyusunan Neraca Spasial Sumberdaya Alam Bagian 1: Sumber Daya Air. Perhitungan kebutuhan air yang tidak dicantumkan dalam SNI 6728.1: 2015 seperti kebutuhan air untuk pertanian, restoran, perhotelan, fasilitas pendidikan, fasilitas kesehatan dan kebutuhan air peribadatan ditentukan berdasarkan pada Triatmodjo (2010). Persamaan yang digunakan untuk menghitung kebutuhan air dalam penelitian ini disajikan dalam Persamaan 3 sampai dengan Persamaan 13.

$\mathrm{KAd}=365 \times\left((q u / 1.000) \times \mathrm{P}_{\mathrm{k}}\right)$

(SNI 6728.1: 2015 dengan modifikasi)

di mana:

KAd = Kebutuhan air domestik perkotaan ( $\mathrm{m}^{3} /$ tahun)

qu $=$ Konsumsi air rata-rata perkotaan $(120$ liter/orang/hari)

$\mathrm{P}_{\mathrm{k}} \quad=$ Jumlah Penduduk kota (orang)

$\mathrm{KSW}=\mathrm{L} \times(365 \times \mathrm{lt}) \times(\mathrm{A} / 1.000)$

(Triadmodjo, 2010 dengan modifikasi)

di mana

$\mathrm{KSW}=$ Kebutuhan air untuk pertanian ( $\mathrm{m}^{3} /$ tahun)

$\mathrm{L}=$ Luas sawah (hektar)

It $\quad=$ Persentase masa tanam selama setahun dalam persen, rata-rata 120 hari per tahun

A $=$ Standar penggunaan air persawahan (1 liter/hektar/detik)

$\mathrm{KPr}=(365 / 1.000) \times \mathrm{q}(\mathrm{f}) \times \mathrm{A}(\mathrm{FP})$.

(SNI 6728.1: 2015 dengan modifikasi)

di mana:

$\mathrm{KPr}=$ Kebutuhan Air untuk Perikanan ( $\mathrm{m}^{3} /$ tahun)

$\mathrm{q}(\mathrm{f})=$ kebutuhan air rata-rata untuk perikanan (4,91 liter/hari)

$\mathrm{A}(\mathrm{FP})=$ luas kolam/tambak (hektar)

$\mathrm{KPt}=(365 / 1.000) \times((\mathrm{q}(\mathrm{tb}) \times \mathrm{P}(\mathrm{tb})+\mathrm{q}(\mathrm{ts}) \times$ $P(t s)+q(t k) \times P(t k))$

(SNI 6728.1: 2015 dengan modifikasi)

di mana:

$\mathrm{KPt}=$ Kebutuhan air untuk peternakan ( $\mathrm{m}^{3} /$ tahun)

$\mathrm{q}(\mathrm{tb})=$ Kebutuhan air rata-rata untuk ternak besar seperti sapi dan kerbau (40 liter/ekor/hari) 
$\mathrm{q}(\mathrm{ts})=$ Kebutuhan air rata-rata untuk ternak sedang seperti kembing, domba dan babi (5 liter/ekor/hari)

$\mathrm{q}(\mathrm{tk})=$ Kebutuhan air rata-rata untuk ternak kecil seperti unggas (0,6 liter/ekor/hari)

$\mathrm{P}(\mathrm{tb})=$ Jumlah ternak besar seperti sapi dan kerbau

$\mathrm{P}(\mathrm{ts}) \quad=$ Jumlah ternak sedang seperti kembing, domba dan babi

$P(t k)=$ Jumlah ternak kecil seperti unggas

$\mathrm{KIn}=\mathrm{Hk} \times(\mathrm{P}(\mathrm{k}) \times \mathrm{q}(\mathrm{k}) / 1.000)$

(SNI 6728.1: 2015 dengan modifikasi)

di mana:

KIn $=$ Kebutuhan air untuk industri ( $\mathrm{m}^{3} /$ tahun)

Hk = Jumlah hari kerja dalam setahun

$\mathrm{P}(\mathrm{k})=$ Jumlah karyawan dalam industri

$q(k)=$ jumlah kebutuhan air rata-rata untuk karyawan dalam industri (10 liter/orang/hari)

KRt $=(365 / 1.000) \times P(r) \times q(r)$

(Triadmodjo, 2010 dengan modifikasi)

di mana:

$\mathrm{KRt}=$ Kebutuhan air untuk restoran ( $\mathrm{m}^{3} /$ tahun)

$P(r) \quad=$ Jumlah restoran

$q(r)=$ Kebutuhan rata-rata untuk restoran (100 liter/kursi/hari)

$\mathrm{KHt}=(365 / 1.000) \times \mathrm{P}(\mathrm{h}) \times \mathrm{q}(\mathrm{h})$

(Triadmodjo, 2010 dengan modifikasi)

di mana:

$\mathrm{KHt}=$ Kebutuhan air untuk hotel ( $\mathrm{m}^{3} /$ tahun)

$\mathrm{P}(\mathrm{h}) \quad=$ Jumlah kamar

$q(h)=$ Kebutuhan rata-rata untuk hotel $(150$ liter/kursi/hari)

$\mathrm{KSk}=(365 / 1.000) \times \mathrm{P}(\mathrm{s}) \times \mathrm{q}(\mathrm{s})$

(Triadmodjo, 2010 dengan modifikasi)

di mana:

$\mathrm{KSK}=$ Kebutuhan air untuk sekolah ( $\mathrm{m}^{3} /$ tahun)

$\mathrm{P}(\mathrm{s}) \quad=$ Jumlah siswa

$q(s)=$ Kebutuhan rata-rata untuk sekolah (10 liter/siswa/hari)
$\mathrm{KKs}=(365 / 1.000) \times \mathrm{P}(\mathrm{ks}) \times \mathrm{q}(\mathrm{ks})$

(Triadmodjo, 2010 dengan modifikasi)

di mana:

KKs = Kebutuhan air untuk fasilitas kesehatan ( $\mathrm{m}^{3} /$ tahun)

$\mathrm{P}(\mathrm{ks}) \quad=$ Jumlah tempat tidur

$\mathrm{q}(\mathrm{ks})=$ Kebutuhan rata-rata untuk fasilitas kesehatan (300 liter/tempat tidur/hari)

$\mathrm{KTi}=(365 / 1.000) \times \mathrm{P}(\mathrm{ti}) \times \mathrm{q}(\mathrm{ti})$

(Triadmodjo, 2010 dengan modifikasi)

di mana:

$\mathrm{KTi}=$ Kebutuhan air untuk fasilitas tempat ibadah ( $\mathrm{m}^{3} /$ tahun)

$\mathrm{P}(\mathrm{ti})=$ Jumlah tempat ibadah

$q(\mathrm{ti})=$ Kebutuhan rata-rata untuk fasilitas tempat ibadah (2 liter/unit/m²)

$\mathrm{KKn}=(365 / 1.000) \times \mathrm{P}(\mathrm{kn}) \times \mathrm{q}(\mathrm{kn})$

(Triadmodjo, 2010 dengan modifikasi)

di mana:

$\mathrm{KKn}=$ Kebutuhan air untuk perkantoran ( $\mathrm{m}^{3} /$ tahun)

$P(k n)=$ Jumlah pegawai

$q(k n)=$ Kebutuhan air rata-rata untuk perkantoran (10 liter/pegawai/hari)

Metode Perhitungan Indeks pemakaian airtanah Perhitungan indeks pemakaian airtanah dilakukan dengan menggunakan persamaan 14. Indeks pemakaian airtanah diartikan sebagai perbandingan antara kebutuhan dengan ketersediaan. Kebutuhan airtanah yang terhitung dalam penelitian ini diasumsikan semua dipenuhi dari airtanah di Kota Yogyakarta. Indeks pemakaian airtanah kemudian dikelaskan sesuai dengan SNI 6728.1: 2015 seperti yang disajikan dalam Tabel 1.

IPAt $=$ KTAt $/$ KAtD

(SNI 6728.1: 2015 dengan modifikasi)

di mana:

IPAT = Indeks pemakaian airtanah

KTAt = Kebutuhan Total Airtanah ( $\mathrm{m}^{3} /$ tahun)

KAtD $=$ Ketersediaan Airtanah Dinamis ( $\mathrm{m}^{3} /$ tahun)

Tabel 1. Klasifikasi Indeks Pemakaian Airtanah (IPAt)

\begin{tabular}{|c|c|c|c|}
\hline No & Klasifikasi & Nilai IPAt & Warna pada Peta \\
\hline 1. & I (tidak Aman) & $>0,40$ & Merah \\
\hline 2. & II (Kurang Aman) & $>0,20-0,40$ & Kuning \\
\hline 3. & III (Cukup Aman) & $>0,10-0.20$ & Hijau \\
\hline 4. & IV (Aman) & $\leq 0,10$ & Biru \\
\hline
\end{tabular}

Sumber: SNI 6728.1: 2015 dengan modifikasi 


\section{HASIL DAN PEMBAHASAN}

Potensi Airtanah Dinamis di Kota Yogyakarta

Kota Yogyakarta merupakan bagian dari

CAT Yogyakarta Sleman yang didominasi oleh akuifer yang terbentuk oleh aktivitas volkanisme Gunungapi Merapi. Kota Yogyakarta terletak di lereng selatan Gunungapi Merapi, menempati lereng bawah Gunungapi Merapi atau Dataran Fluviovulkanik Gunungapi Merapi. Akuifer terdiri atas Formasi Yogyakarta dan Formasi Sleman. Kota Yogyakarta terdiri atas dua kelas produktivitas akuifer disertai Gambar 1.

Santosa dan Adji (2014) menyebutkan bahwa Kota Yogyakarta terletak pada suatu bagian graben yang terbentuk karena adanya patahan di bagian Utara dan Selatan Kota Yogyakarta. Hal ini menyebabkan ketebalan akuifer di Kota Yogyakarta termasuk cukup tebal yakni sekitar 80 meter sampai dengan 110 meter. Gambar 2 menunjukkan bahwa ketebalan akuifer di Kota Yogyakarta didominasi oleh ketebalan akuifer antara $100-120$ meter. Hanya sedikit wilayah di bagian Tenggara yang memiliki ketebalan akuifer $80-100$ meter. Hal ini karena pada lokasi tersebut dekat dengan batuan dasar yang melampar dari tubuh gunungapi tersier yang membentuk Perbukitan Baturagung di Bagian Timur Kota Yogyakarta.

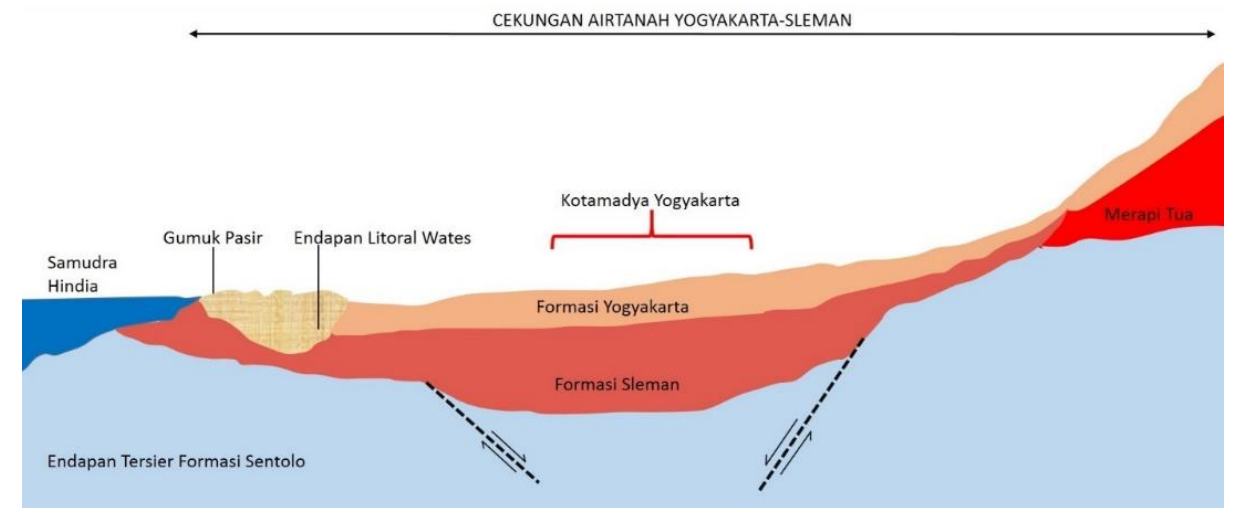

Gambar 1. Skematik Formasi Penyusun Cekungan Airtanah Yogyakarta-Sleman dan Kedudukan Kota Yogyakarta di Dalamnya (Modifikasi dari Santosa dan Adji, 2014)

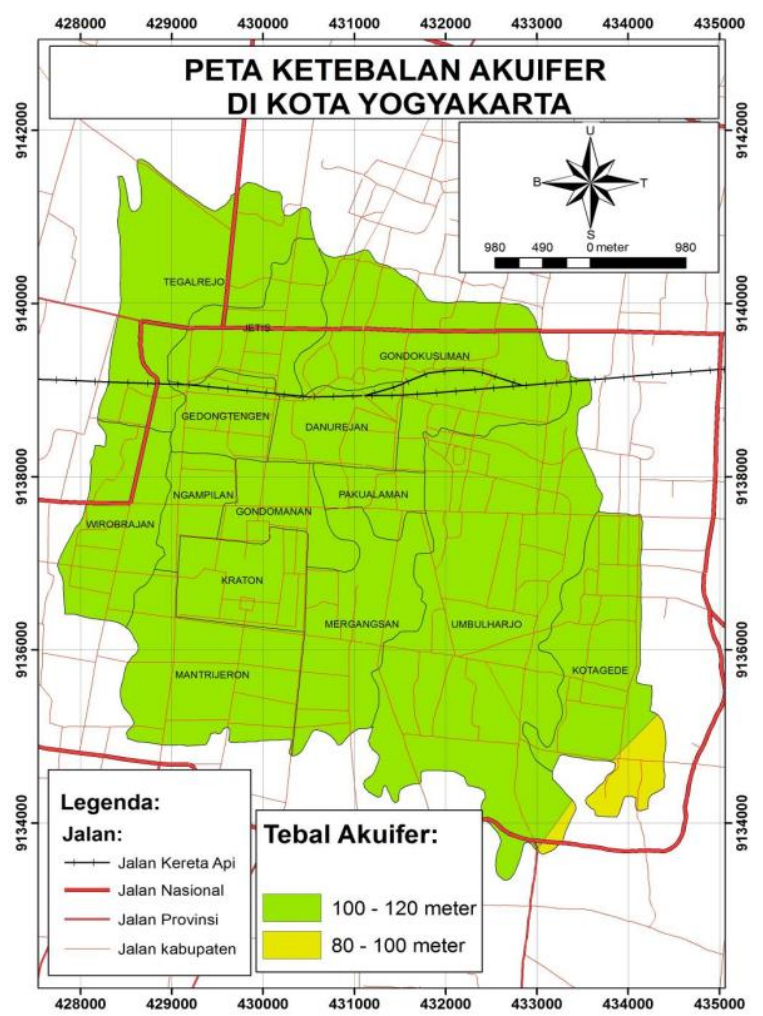

Gambar 2. Peta Ketebalan Akuifer di Kota Yogyakarta (Tim Fakultas Teknik Universitas Gadjah Mada, 2011) 
Tabel 2 menunjukkan hasil perhitungan ketersediaan airtanah dinamis di kota Yogyakarta untuk setiap kecamatan. Nilai tersebut menunjukkan bahwa ketersediaan airtanah di Kota Yogyakarta lebih dari 1,1 $\mathrm{km}^{3} /$ tahun. Nilai ketersediaan airtanah untuk setiap kecamatan mulai dari 16,5 juta $\mathrm{m}^{3} /$ tahun sampai dengan 87,6 juta $\mathrm{m}^{3} /$ tahun.

Akuifer di Kota Yogyakarta dibagi dua bagian, yakni airtanah dangkal dan airtanah dalam. Pembagian ini dilakukan oleh
MacDonald and Partners (1984) yang didasarkan pada rata-rata kedalaman Formasi Yogyakarta yakni 40 meter. Berdasarkan hal tersebut, maka pada Tabel 3 disajikan nilai potensi airtanah dinamis pada masing-masing lapisan akuifer di Kota Yogyakarta. Pembagian ini dimaksudkan untuk mengetahui potensi airtanah dangkal yang umum digunakan oleh masyarakat Kota Yogyakarta melalui sumur rumah tangga.

Tabel 2. Ketersediaan Airtanah Dinamis pada Masing-masing Kecamatan di Kota Yogyakarta

\begin{tabular}{llr}
\hline & \multicolumn{1}{c}{ Kocamatan } & Ketersediaan Airtanah Dinamis (m ${ }^{3} /$ Tahun) \\
\hline 1 & Danurejan & 16.498 .374 \\
2 & Gedong Tengen & 48.277 .832 \\
3 & Gondokusuman & 87.636 .652 \\
4 & Gondomanan & 54.050 .812 \\
5 & Jetis & 44.767 .244 \\
6 & Kotagede & 25.769 .958 \\
7 & Kraton & 41.849 .533 \\
8 & Mantrijeron & 49.736 .372 \\
9 & Mergangsan & 48.904 .452 \\
10 & Ngampilan & 41.240 .258 \\
11 & Pakualaman & 45.388 .188 \\
12 & Tegalrejo & 82.045 .634 \\
13 & Umbulharjo & 37.932 .447 \\
14 & Wirobrajan & 31.874 .066 \\
\hline & Total Ketersediaan & 1.116 .416 .030 \\
\hline
\end{tabular}

Sumber: Tim Fakultas Teknik UCM (2010)

Tabel 3. Ketersediaan Airtanah Dinamis pada Dua Lapisan Akuifer di Kota Yogyakarta

\begin{tabular}{llrr}
\hline No & Kecamatan & $\begin{array}{c}\text { Ketersediaan Airtanah Bagian Atas } \\
\text { (Dangkal) }\end{array}$ & Ketersediaan Airtanah Bagian Bawah (Dalam) \\
\hline 1 & Danurejan & $4,499,557$ & $11,998,817$ \\
2 & Gedong & $13,166,681$ & $35,111,151$ \\
& Tengen & $23,900,905$ & $63,735,747$ \\
3 & Gondokusuma & & \\
& $n$ & $14,741,131$ & $39,309,681$ \\
4 & Condomanan & $12,209,248$ & $32,557,996$ \\
5 & Jetis & $7,028,170$ & $18,741,788$ \\
6 & Kotagede & $11,413,509$ & $30,436,024$ \\
7 & Kraton & $13,564,465$ & $36,171,907$ \\
8 & Mantrijeron & $13,337,578$ & $35,566,874$ \\
9 & Mergangsan & $11,247,343$ & $29,992,915$ \\
10 & Ngampilan & $12,378,597$ & $33,009,591$ \\
11 & Pakualaman & $22,376,082$ & $59,669,552$ \\
12 & Tegalrejo & $10,345,213$ & $27,587,234$ \\
13 & Umbulharjo & $8,692,927$ & $23,181,139$ \\
14 & Wirobrajan & $178,901,406$ & $477,070,416$ \\
\hline Jumlah & & & \\
\hline
\end{tabular}

Sumber: Hasil Perhitungan (2019)

\section{Kebutuhan Air di Kota Yogyakarta}

Tabel 4 menunjukkan kebutuhan air untuk semua sektor di masing-masing kecamatan di Kota Yogyakarta. Total kebutuhan air di Kota Yogyakarta dalam 20,5 juta $\mathrm{m}^{3} /$ tahun. Hal ini berarti bahwa dengan jumlah penduduk pada tahun 2018 adalah sejumlah 422.732 jiwa, maka kebutuhan air rata-rata adalah sebesar $48,44 \mathrm{~m}^{3} /$ tahun (kebutuhan domestik dan non-domestik). 
Tabel 4. Kebutuhan Air Masing-masing Kecamatan di Kota Yogyakarta

\begin{tabular}{lrr}
\hline \multicolumn{1}{c}{ Kecamatan } & $\begin{array}{c}\text { Kebutuhan Air } \\
\left(\mathrm{m}^{3} / \text { Tahun }\right)\end{array}$ & Persentase \\
\hline Danurejan & 898.735 & 4,39 \\
Gedong Tengen & 932.921 & 4,56 \\
Gondokusuman & 2.331 .361 & 11,39 \\
Gondomanan & 684.763 & 3,34 \\
Jetis & 1.100 .849 & 5,38 \\
Kotagede & 1.712 .476 & 8,36 \\
Kraton & 820.145 & 4,01 \\
Mantrijeron & 1.570 .917 & 7,67 \\
Mergangsan & 1.522 .527 & 7,44 \\
Ngampilan & 814.679 & 3,98 \\
Pakualaman & 440.281 & 2,15 \\
Tegalrejo & 1.904 .304 & 9,30 \\
Umbulharjo & 4.524 .728 & 22,10 \\
Wirobrajan & 1.216 .785 & 5,94 \\
Total Kebutuhan & 20.475 .471 & 100,00 \\
\hline
\end{tabular}

Sumber: Hasil Analisis Data (2019)

Kebutuhan air di Kota Yogyakarta yang paling banyak adalah kebutuhan air untuk keperluan domestik, yakni sebesar 90,43\%. Jumlah lainnya tidak terlalu besar jika dibandingkan dengan jumlah kebutuhan untuk domestik ini. Kebutuhan yang juga cukup besar adalah pertanian yakni sebesar 2,53\%, meskipun luas sawah di Kota Yogyakarta hanya seluas 50 hektar. Kebutuhan air untuk Sektor pertanian secara umum (pertanian, perikanan dan peternakan) jumlahnya $2,56 \%$, lebih sedikit dibandingkan dengan sektor jasa (selain domestik dan pertanian secara umum) yakni sebesar 7.01\%. Hal ini menunjukkan sifat perkotaannya jauh lebih dominan dari sifat perdesaannya.

Tabel 4. Kebutuhan Air Masing-masing Jenis Penggunaan (Sektor) di Kota Yogyakarta

\begin{tabular}{lrr}
\hline Jenis Penggunaan & Kebutuhan Air & Persentase \\
\hline Domestik & $18.515 .662,00$ & 90,43 \\
Pertanian & $518.400,00$ & 2,53 \\
Perikanan & 0,64 & 0,01 \\
Peternakan & $6.530,14$ & 0,03 \\
Industri & $40.922,97$ & 0,20 \\
Restoran & $175.930,00$ & 0,86 \\
Sekolah & $301.368,00$ & 1,47 \\
Kesehatan & $246.265,00$ & 1,20 \\
Perkantoran & $19.141,00$ & 0,09 \\
Tempat lbadah & $70.518,00$ & 0,34 \\
Perhotelan & $580.733,00$ & 2,84 \\
Total Kebutuhan & $20.475 .470,75$ & 100.00 \\
\hline
\end{tabular}

Sumber: Hasil Analisis Data (2019)

\section{Indeks Pemakaian Airtanah di Kota Yogyakarta}

Hasil perhitungan indeks pemakaian airtanah di Kota Yogyakarta disajikan dalam Tabel 5. Nilai indeks pemakaian airtanah tertinggi berada di Kecamatan Umbulharjo yaitu 0,12 dan nilai terendah berada di Kecamatan Gondomanan, dan Pakualaman sebesar 0,01. Secara keseluruhan, Kota Yogyakarta memiliki indeks pemakaian airtanah 0,02 , yang berarti masuk dalam klasifikasi kelas IV (aman). Kelas IV merupakan klasifikasi yang paling rendah yang berarti bahwa ketersediaan airtanah di Kota Yogyakarta dalam kondisi aman atau masih dapat memenuhi kebutuhan air masyarakat Kota Yogyakarta. 
Tabel 5. Indeks Pemakaian Airtanah di Kota Yogyakarta

\begin{tabular}{rlcc}
\hline \multicolumn{1}{c}{ No Kocamatan } & & Indeks Pemakaian Airtanah & Klasifikasi \\
\hline 1 & Danurejan & 0,05 & IV \\
2 & Gedong Tengen & 0,02 & IV \\
3 & Gondokusuman & 0,03 & IV \\
4 & Gondomanan & 0,01 & IV \\
5 & Jetis & 0,02 & IV \\
6 & Kotagede & 0,07 & IV \\
7 & Kraton & 0,02 & IV \\
8 & Mantrijeron & 0,03 & IV \\
9 & Mergangsan & 0,03 & IV \\
10 & Ngampilan & 0,02 & IV \\
11 & Pakualaman & 0,01 & IV \\
12 & Tegalrejo & 0,02 & IV \\
13 & Umbulharjo & 0,12 & III \\
14 & Wirobrajan & 0,04 & IV \\
& Kota Yogyakarta & 0,02 & IV \\
\hline
\end{tabular}

Sumber: Hasil Analisis Data (2019)

Hasil yang diperoleh dari Tabel 5 menunjukkan kondisi yang tidak sesuai dengan fakta di lapangan di mana banyak warga masyarakat yang mengalami kesulitan memperoleh air bersih ketika musim kemarau dan harus memperdalam sumur yang digunakan agar mendapatkan airtanah (Tim Fakultas Geografi UGM, 2014). Fakta lain seperti hasil kajian yang dilakukan oleh Wilopo (1999) juga menunjukkan adanya penurunan muka airtanah yang terus berlangsung sejak tahun 1983, sehingga semestinya kondisi airtanah di Kota Yogyakarta tidak dalam kondisi aman. Oleh karena itu, penelitian ini mendekati dengan perhitungan indeks pemakaian airtanah yang dihitung dari kebutuhan total air bersih dibagi dengan ketersediaan airtanah dinamis pada akuifer bagian atas (airtanah dangkal). Hal ini sesuai dengan kajian yang dilakukan oleh Putra (2011) dan Tim Fakultas Geografi UGM (2014) yang menyatakan bahwa masyarakat di Kota Yogyakarta umumnya menggunakan airtanah dangkal.

Tabel 6 menunjukkan hasil indeks pemakaian airtanah dangkal. Hasil menunjukkan bahwa secara umum Kota Yogyakarta masuk dalam klasifikasi III yang berarti pemakaian airtanah dangkal secara umum masih cukup aman. Namun demikian, secara rinci dapat kita lihat bahwa terdapat satu kecamatan dengan klasifikasi I (tidak aman) dan satu kecamatan dengan klasifikasi II (kurang aman).

Tabel 6. Indeks Pemakaian Airtanah Dangkal di Kota Yogyakarta

\begin{tabular}{|c|c|c|c|}
\hline No & Kecamatan & Indeks Pemakaian Airtanah & Klasifikasi \\
\hline 1 & Danurejan & 0.20 & III \\
\hline 2 & Gedong Tengen & 0.07 & IV \\
\hline 3 & Gondokusuman & 0.10 & IV \\
\hline 4 & Gondomanan & 0.05 & IV \\
\hline 5 & Jetis & 0.09 & IV \\
\hline 6 & Kotagede & 0.24 & II \\
\hline 7 & Kraton & 0.07 & IV \\
\hline 8 & Mantrijeron & 0.12 & III \\
\hline 9 & Mergangsan & 0.11 & III \\
\hline 10 & Ngampilan & 0.07 & IV \\
\hline 11 & Pakualaman & 0.04 & IV \\
\hline 12 & Tegalrejo & 0.09 & IV \\
\hline 13 & Umbulharjo & 0.44 & 1 \\
\hline 14 & Wirobrajan & 0.14 & III \\
\hline & Kota Yogyakarta & 0.11 & III \\
\hline
\end{tabular}

Sumber: Hasil Analisis Data (2019)

Berdasarkan pada analisis yang dilakukan, diketahui bahwa faktor yang paling berpengaruh terhadap nilai indeks pemakaian airtanah yang tinggi disebabkan oleh jumlah penduduk yang besar. Hal ini karena dari perhitungan kebutuhan air diketahui bahwa kebutuhan air terbesar disumbang oleh kebutuhan air domestik (90,43\%). Wilayah Kecamatan Kota Gede dan Umbulharjo yang terletak di pinggiran Kota Yogyakarta (Gambar 3) dan jauh dari Central Business District $(C B D)$ atau Daerah Pusat Kegiatan (DPK), sehingga dominasi penggunaan lahan 
terbangunnya adalah untuk permukiman. Hal ini menyebabkan jumlah penduduk yang tinggi dan kebutuhan airtanah menjadi sangat tinggi.

Penurunan indeks pemakaian airtanah dapat dikurangi dengan memberikan alternatif sumber air bersih misalnya dari pengolahan air sungai, meskipun saat ini banyak sungai di Yogyakarta telah mengalami pencemaran yang cukup parah (Suprayogi et al., 2019). Oleh karenanya diperlukan infrastruktur pengolahan air bersih seperti yang telah ada di banyak kota besar di dunia ataupun di Indonesia. Ketersediaan air permukaan menurut penelitian yang dilakukan oleh Tim Fakultas Geografi UGM (2019) adalah sekitar
$425,352,356 \mathrm{~m}^{3} /$ tahun atau dua kali ketersediaan airtanah dinamis pada airtanah dangkal. Saat ini, Pemerintah daerah Istimewa Yogyakarta telah memulai instalasi pengolahan air Sungai Progo yang akan digunakan sebagai sumber utama air bersih Perusahaan Daerah Air Minum. Usaha tersebut jika berhasil akan menurunkan indeks penggunaan airtanah di Kota Yogyakarta, sehingga dampak buruk seperti semakin menurunnya muka airtanah dan subsidence (penurunan muka tanah) dapat dihindarkan di masa mendatang.

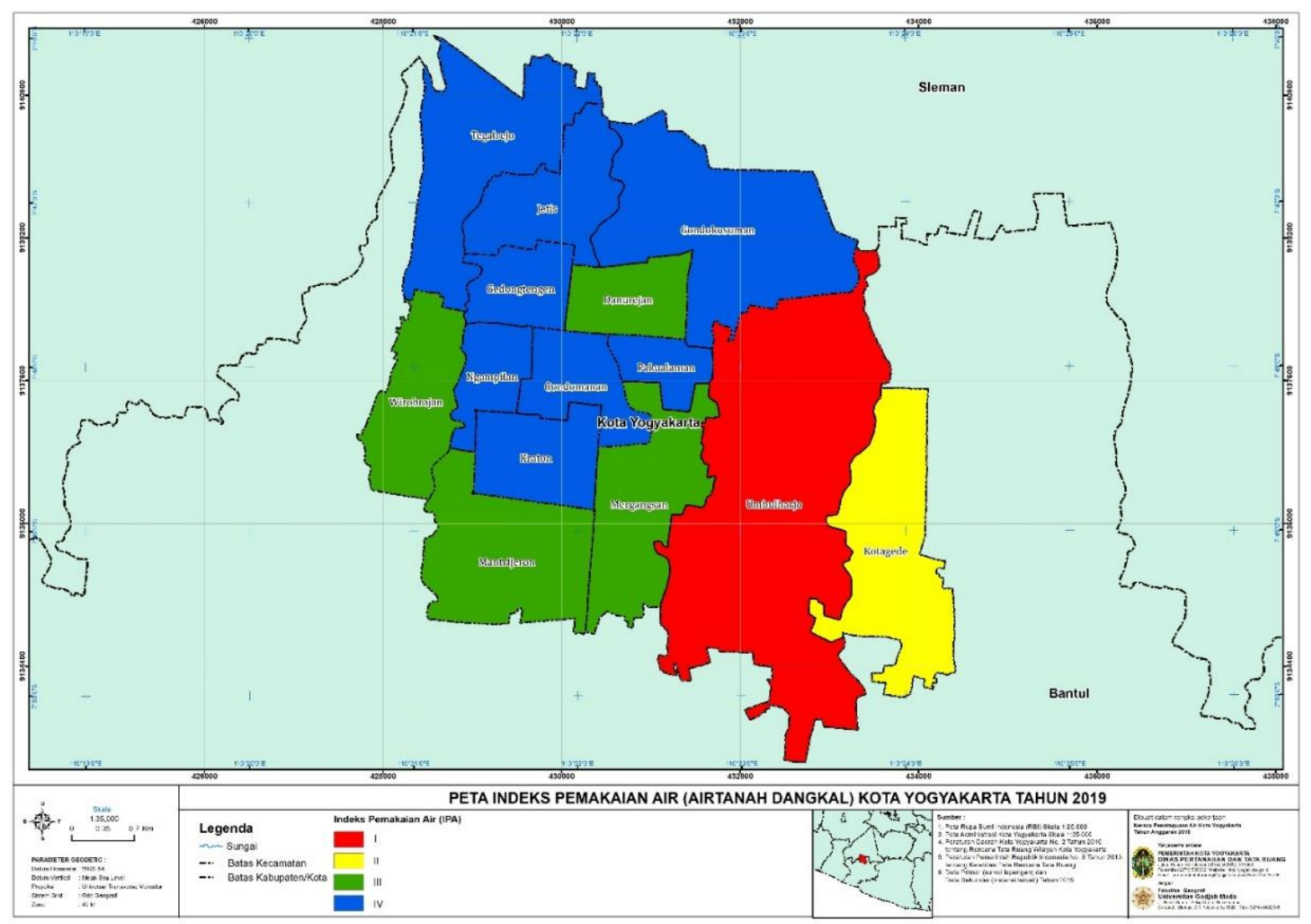

Gambar 3. Peta Indeks Pemakaian Airtanah Dangkal di Kota Yogyakarta

\section{KESIMPULAN}

Berdasarkan hasil penelitian yang dilakukan diketahui bahwa secara umum indeks pemakaian airtanah di Kota Yogyakarta adalah dalam kondisi aman. Namun demikian, pada indeks pemakaian airtanah dangkal menunjukkan satu kecamatan pada klasifikasi kurang aman (II) dan satu kecamatan pada klasifikasi tidak aman (I). Faktor utama yang menyebabkan tingginya indeks pemakaian airtanah dangkal adalah jumlah penduduk yang besar yang menyebabkan kebutuhan air untuk domestic menjadi sangat besar, yakni sampai dengan 90,43\% dari total kebutuhan air.

\section{UCAPAN TERIMA KASIH}

Penelitian ini merupakan bagian dari laporan penelitian berjudul "Penyusunan Neraca Penatagunaan Air Kota Yogyakarta tahun 2019" yang merupakan kerjasama antara Dinas 
Pertanahan dan Tata Ruang, Pemerintah Kota Yogyakarta dengan Fakultas Geografi, Universitas Gadjah Mada. Penulis mengucapkan terima kasih sebesar-besarnya atas bantuan semua pihak, sehingga penelitian ini dapat diselesaikan dengan baik dan dipublikasikan oleh penulis.

\section{DAFTAR PUSTAKA}

Allen, A. (2007). Urban Groundwater Problems in Cork City, Southwest Ireland. In Howard, K.W.F. (ed). Urban Groundwater - Meeting the Challenge. Tailor \& Francis, London.

Burn, S., Eiswirth, M., Correll, R., Cronin, A., Desilva, D., Diaper, C., Dillon, P., Mohrlok, U., Morris, B., Rueedi, J., Wolf, L., Vizintin, G. and Vött, U. (2007). Urban Infrastructure and Its Impact on Groundwater Contamination. In Howard, K.W.F. (ed). Urban Groundwater Meeting the Challenge. Tailor \& Francis, London.

Cahyadi, A., Dipayana, G.A., Rahmat, P.N. dan Hartoyo, F.A. (2011). Pemetaan Kerentanan Airtanah dan Peranannya dalam Perencanaan Pengembangan Permukiman (Studi Kasus Kecamatan Piyungan Kabupaten Bantul). Prosiding Seminar Nasional Peningkatan Kehidupan Masyarakat yang Madani dan Lestari. Universitas Islam Indonesia, Yogyakarta.

Cahyadi, A., Priadmodjo, A., and Yananto, A. (2011). Critizing the Conventional of Urban Drainage. Proceeding The $3^{\text {rd }}$ International Graduated Student Conference on Indonesia. Graduate School of Universitas Gadjah Mada, Yogyakarta.

Chilton, J. (1999). Groundwater in the Urban Environment, Volume I. Tailor \& Francis, London.

Chilton, J. (1999). Groundwater in the Urban Environment: Selected City Profiles. A.A. Balkema, Rotterdam.

Garcia-Fresca, B. (2007). Urban-enhanced Groundwater Recharge: Review and Case Study of Austin, Texas, USA. In Howard, K.W.F. (ed). Urban Groundwater Meeting the Challenge. Tailor \& Francis, London.

Hendrayana, H. dan Vicente, V.A.D. (2013). Cadangan Air Tanah Berdasarkan Geometrid an Konfigurasi Sistem Akuifer Cekungan Air Tanah Yogyakarta-Sleman. Prosiding Seminar Nasional Kebumian Ke-
6. Jurusan Teknik Geologi, Fakultas Teknik, Universitas Gadjah Mada.

Howard, K.W.F. (2007). Introduction: Urban Groundwater - Meeting the Challenge. Tailor \& Francis, London.

MacDonald and Partners. (1984). Greater Yogyakarta Groundwater Resources Study, Vol.3. Research Report. Directorate General of Water Resources Groundwater Development Project, Ministry of Public Works, Government of The Republic of Indonesia.

Margat, J. and van der Gun, J. (2013). Groundwater Around the World: A Geographic Synopsis. CRC Press, Boca Raton.

Miracapillo, C. (2007). Groundwater Modelling to Evaluate the Risk of Aquifer Depletion due to a Constriction Site in an Urban Area in Basel, Swtzerland. In Howard, K.W.F. (ed). Urban Groundwater - Meeting the Challenge. Tailor \& Francis, London.

Mohrlok, U., Cata, C. and Bücker-Gittel, M. (2007). Impact on Urban Groundawter by Wastewater infiltration into Soils. In Howard, K.W.F. (ed). Urban Groundwater - Meeting the Challenge. Tailor \& Francis, London.

Putra, D.P.E. (2003). Integrated Water Resources Management in Merapi Yogyakarta Basin. Laporan Penelitian. AUNSeed/net - Fakultas Teknik Universitas Gadjah Mada.

Putra, D.P.E. (2011). Evolution of Groundwater Chemistry on Shallow Aquifer of Yogyakarta City Urban Area. Journal of South East Asian Applied Geology, 3(2): 116 $-124$.

Purnama, S. (2010). Hidrologi Airtanah. Kanisius, Yogyakarta.

Purnama, S., Tivianton, T.A., Cahyadi, A. dan Febriarta, E. (2019). Kajian daerah Imbuhan Airtanah di Kabupaten Ngawi. Jurnal Geografi, 16(1): 54 - 59.

Tood, D.K. and Mays. L.W. (2005). Groundwater Hydrology. John Willey \& Sons, New York.

Triatmodjo, B. (2010). Hidrologi Terapan. Beta Offset, Yogyakarta.

Sari, F.A. 2015. Pemodelan Aliran Airtanah di Wilayah Cekungan Airtanah YogyakartaSleman Bagian Barat. Skripsi Fakultas Teknik Univeristas Gadjah Mada. Yogyakarta.

Santosa, L. dan Adji, T.N. (2014). Karakteristik Akuifer dan Potensi Airtanah di Graben Bantul. Gadjah Mada University Press, Yogyakarta. 
Standar Nasional Indonesia (SNI) 6728.1: 2015. (2015). Penyusunan Neraca Spasial Sumber Daya Alam-Bagian 1: Sumber Daya Air. Badan Standardisasi Nasional (BSN). Jakarta.

Suprayogi, S., Marfai, M.A., Cahyadi, A., Latifah, R. and Fatchurohman, H. (2019). Anlyzing the Characteristics of Domestic Wastes in Belik River, the Special Region of Yogykarta, Indonesia. ASEAN Journal on Science and Technology for Development, 36(3): $97-102$.

Tim Fakultas Geografi UCM. (1996). Penyusunan Rencana Zona Tata Guna Air Bawah Tanah Di Kabupaten Bantul dan Pembuatan Peta Digital Zona Tata Guna Air Bawah Tanah Untuk Kabupaten Sleman, Kodya Yogyakarta, dan Kabupaten Bantul, Provinsi Daerah Istimewa Yogyakarta. Laporan Penelitian. Dinas Pertambangan Provinsi Daerah Istimewa Yogyakarta.

Tim Fakultas Geografi UGM. (2014). Kajian Kebijakan Pengelolaan Cekungan Airtanah Yogyakarta-Sleman (Kabupaten Sleman, Kota Yogyakarta dan Kabupaten Bantul). Laporan Penelitian. Biro Administrasi Perekonomian dan Sumberdaya Alam, Sekertariat Daerah Pemerintah Daerah Istimewa Yogyakarta.

Tim Fakultas Geografi UGM. (2015). Kajian Kuantitas Airtanah Dalam di Kota Yogyakarta. Laporan Penelitian. Dinas Lingkungan Hidup Kota Yogyakarta.

Tim Fakultas Geografi UGM. (2019). Penyusunan Neraca Penatagunaan Air Kota Yogyakarta tahun 2019. Laporan Penelitian. Dinas Pertanahan dan Tata Ruang, Pemerintah Kota Yogyakarta.

Tim Fakultas Teknik UGM. (2010). Penentuan Geometri Cekungan Air Tanah YogyakartaSleman. Laporan Penelitian. Dinas Pekerjaan Umum Perumahan dan Energi Sumberdaya Mineral Daerah Istimewa Yogyakarta.

Tim Fakultas Teknik UGM. (2011). Pemetaan Zonasi Konservasi Air Tanah di Cekungan Air Tanah Yogyakarta-Sleman. Laporan Penelitian. Dinas Pekerjaan Umum Perumahan dan Energi Sumberdaya Mineral Daerah Istimewa Yogyakarta.

Wilopo, W. (1999). Perencanaan Konservasi Air Bawah Tanah di Cekungan Yogyakarta, Daerah Istimewa Yogyakarta. Skripsi Fakultas Teknik Univeristas Gadjah Mada. Yogyakarta. 
